\title{
Exchange Traded Funds: History, Trading and Research
}

Laurent Deville

Paris-Dauphine University, CNRS, DRM-CEREG

Laurent.Deville@dauphine.fr

June 2006

Key words: literature review, Exchange Traded Funds 


\section{Introduction}

One of the most spectacular successes in financial innovation since the advent of financial futures is probably the creation of Exchange Traded Funds (ETFs). As index funds, they aim at replicating the performance of their benchmark indices as closely as possible. Contrary to conventional mutual funds, however, ETFs are listed on an exchange and can be traded intradaily. Issuers and exchanges set forth the diversification opportunities they provide to all types of investors at a lower cost, but also highlight their tax efficiency, transparency and low management fees. All of these features rely on a specific "in-kind" creation and redemption principle: new shares can continuously be created by depositing a portfolio of stocks that closely approximates the holdings of the fund and similarly, investors can redeem outstanding ETF shares and receive the basket portfolio in return. Holdings are transparent since fund portfolios are disclosed at the end of the trading day.

ETFs were introduced on U.S. and Canadian exchanges in the early 90s. In the first several years, they represented a small fraction of the assets under management in index funds. However, the 132\% average annual growth rate of ETF assets from 1995 through 2001 (Gastineau, 2002) illustrates the increasing importance of these instruments. The launching of Cubes in 1999 was accompanied by a spectacular growth in trading volume, making the major ETFs the most actively traded equity securities on the U.S. stock exchanges. Since then, ETF markets have continued to grow, not only in the number and variety of products, but also in terms of assets and market value. Initially, they aimed at replicating broad-based stock indices, new ETFs extended their fields to sectors, international markets, fixed-income instruments and lately commodities. By the end of 2005, 453 ETFs were listed around the world for assets worth $\$ 343$ billion. In the U.S., overall ETF assets totalled \$296.02 billion, compared to $\$ 8.9$ trillion in mutual funds ${ }^{1}$.

ETFs were initially developed in the U.S. by the American Stock Exchange (AMEX), but soon faced competition for trading. Before the NYSE ventured into ETFs, these securities were already traded on the Nasdaq InterMarket, regional exchanges, and the Island Electronic Crossing Network. Though long opposed to this practice, for the first time in its history the NYSE began trading the three most active ETFs under Unlisted Trading Privileges on July 31, 2001. Moreover, the different trading venues also competed for listings. On December 1, 
2004, Nasdaq-100 Index Tracking Stocks, more commonly known as "Cubes", changed listing from the AMEX to Nasdaq. More recently, on July 20, 2005, Barclays Global Investors announced the transfer of 61 iShares ETFs to the NYSE from the AMEX.

Even though they received extraordinary press coverage, few academic researches were devoted to the study of ETFs prior to 2000. This only with the spectacular growth ETFs experienced since the launch of Cubes that a more extensive literature focused on these securities. ETFs are in competition with existing index securities: index component stocks, index futures and options contracts and naturally, index mutual funds and closed-end funds. ETFs may be primarily seen as highly redundant assets that should not affect the prevailing established equilibriums. Nonetheless, their success suggests that they filled a gap in investors' needs. The considerable trading volume is likely to impact the markets for the related securities. Research in ETFs is built on the basis of three main topics, all studied from an empirical viewpoint:

- does the ETF specific structure allow for more efficient index fund pricing?

- do ETFs represent a performing alternative to conventional index mutual funds?

- what impact does the advent of ETFs has on trading and market quality with regard to index component stocks and index derivatives?

Other empirical studies also focus on ETFs and investigate diverse topics, such as competition between trading venues, the shape of the demand curve or the use of ETFs. Even though they are only loosely related, we will discuss these studies under the heading "other research related to ETFs".

In the following section, we start by providing an overview of the history of ETFs, from their creation in North-American markets to their more recent developments in the U.S. and European markets. In section 3, we detail the mechanics of ETFs with a special focus on creation and redemption and present the ETF industry. The next four sections are devoted to the survey itself. In section 4, we look at the pricing efficiency of ETFs and compare it to that of closed-end funds, while in section 5 we examine the relative performance of ETFs over conventional index mutual funds. In section 6, we explore the impact the arrival of ETFs has on the market quality of the stock components of the underlying indices, the efficiency of index derivatives markets and the pricing discovery process for index prices. In section 7 , we

\footnotetext{
${ }^{1}$ Data from the Investment Company Institute; http://www.ici.org/.
} 
discuss other, less studied ETF-related issues. Section 8 concludes and presents directions for further research.

\section{The History of ETFs}

\subsection{The Birth and Development of ETFs in North America ${ }^{2}$}

Depending on how restrictive the authors are in their definition, ETFs as we now know them were first introduced in the early 1990s, either in Canada (with the TIPs that were first traded in 1990) or three years later in the U.S. (with the SPDRs). However, the ability to trade a whole stock basket in a single transaction dates further back. Major US brokerage firms provided such program trading facilities as early as the late 1970s, particularly for the S\&P 500 index. With the introduction of index futures contracts, program trading became more popular. As such, the opportunity to develop a suitable instrument allowing index components to be negotiated in a single trade became increasingly interesting.

In 1989, the American Stock Exchange and the Philadelphia Stock Exchange started trading Index Participation Shares (IPS). These synthetic instruments were aimed at replicating the performance of the S\&P 500 index, among others, but they had characteristics similar to those of futures contracts. Despite significant interest from investors, IPS had to stop trading after the lawsuit by the Chicago Mercantile Exchange and the Commodity Futures Trading Commission (CFTC) was won. As futures contracts, IPS had to be traded on a futures exchange regulated by the CFTC.

The first equity-like index fund, the Toronto Index Participation units (TIPs), was introduced on the Toronto Stock Exchange on March 9, 1990. Tracking the Toronto 35, they were traded on the stock exchange and were characterized by extremely low management fees, given that the fund manager was authorized to loan the stocks held by the fund, for which demand was usually high. This product was followed in 1994 by HIPs, based on the broader TSE-100 index. Despite the huge success of these securities, their very low expense ratios finally made them too costly for the exchange and its members. TIPs and HIPs were terminated in $2000^{3}$. In 1993, after three years of dispute with the SEC, the American Stock

\footnotetext{
${ }^{2}$ A more exhaustive presentation of the premises and early development of ETF-like products and ETFs in the US and Canadian markets can be found in Gastineau (2001, 2002) and Blank and Lam (2002).

${ }^{3}$ In 1999, S\&P acquired the rights to the TSE index family and the TSE-30 and TSE-100 indices were combined into the S\&P/TSE-60. Owners of TIPs and HIPs then had to choose between redemption and conversion into the
} 
Exchange (AMEX) began trading Standard \& Poor's 500 Depositary Receipt (SPDR, popularly known as "Spider", ticker SPY), which is often referred to as the world's first ETF. The fund was sponsored by PDR Services Corporation, an AMEX subsidiary, with State Street Bank and Trust as trustee. Its specific trust structure and trading process then constituted a model for the next ETFs introduced, such as MidCap SPDRs, Diamonds (ticker DIA), based on the Dow Jones Industrial Average, or Select Sector SPDRs. In 1996, Barclays Global Investors preferred a mutual fund structure for their WEBS (World Equity Benchmark Shares), ETFs that track the performance of foreign markets indices. Despite a growing interest, it took a few years for these funds to really take off.

The ETF marketplace experienced its effective boom in March 1999 with the launch of the Nasdaq-100 Index Tracking Stock, popularly known as Cubes or Qubes in reference to its initial ticker, QQQ, recently changed to QQQQ. In its second year of trading, a daily average of 70 million shares was being traded in Cubes, which is roughly $4 \%$ of the Nasdaq trading volume. The popularity of this specific fund increased market awareness for the other ETFs and the total assets under management more than doubled in 2000, up to $\$ 70$ billion at the end of December (Frino and Gallagher, 2001). Since then, growth in ETF assets has shown no signs of slowing in the US: $27 \%$ in $2001,23 \%$ in $2002,48 \%$ in $2003,50 \%$ in 2004 , even remaining high at $31 \%$ in $2005^{4}$. Over the years, ETFs progressively became an alternative to traditional non-traded index mutual funds which led their major competitors such as Vanguard or Fidelity to lower their fees by up to 10 basis points or less.

By the end of 2002, there were 113 ETFs in the US with about $\$ 102.14$ billion in assets under management. At the end of April 2006, with new cash invested in the existing ETFs and new ETFs based on still more diverse types of indices launched, the ETF marketplace consisted of four stock exchanges listing 216 ETFs with $\$ 335$ billion in assets. The iShares (sponsored by Barclays Global Investors) and StreetTracks (sponsored by State Street Global Advisors) series present an extremely diversified offer among sectors and/or countries, but ETF assets are dominated by Spider, Cube and Diamond, which are based on relatively broad market indexes. Trading volume concentrates on the two most popular ETFs, Cubes and Spiders, with annual turnovers as high as $3700 \%$ for the former and $2400 \%$ for the latter, according to Bogle (2004). This makes Cubes, a passive investment instrument, the most

i60 Fund based on this new index, the first ETF managed by Barclays Global Investors. Biktimirov (2004) analyzes the conversion of the remaining assets to examine the effect of demand on stock prices.

${ }^{4}$ Data source: Investment Company Institute. 
actively traded listed equity security in the U.S. in 2005, with a daily average of 97 million shares traded.

\subsection{The Market for ETFs in Europe ${ }^{5}$}

European stock exchanges started listing their first ETFs in 2000, while they had already gained popularity in the U.S. The first exchanges to quote ETFs in Europe were the Deutsche Börse and the London Stock Exchange in April 2000 with the opening of the XTF and extraMARK specific market segments. Competition rapidly intensified with the entry of the Stockholm Stock Exchange at the end of October 2000, Euronext in January 2001 when NextTrack began trading ETFs first in Paris and Amsterdam marketplaces, (trading in Brussels began in October 2002) and of the Swiss Stock Exchange in March 2001. In February of 2002, the Helsinki Stock Exchange listed its first ETF, the IHEX 35, whereas the Borsa Italiana opened the MTF segment dedicated to ETFs in September. More recently, ETFs were launched in the Icelandic market (December 2004), the Norwegian market (March 2005), the Irish market (April 2005) and the Austrian market (November 2005).

As of the end of 2005, eleven exchanges listed more than 160 ETFs, with assets growing at an annual rate of $60 \%$ up to $€ 45$ billion. Following the same trend as the one observed in the U.S., exchanges began by quoting broad-based national and regional equity index ETFs. They then quickly diversified the benchmarks to a variety of underlying indices. For example, after only six and five years, respectively, Euronext and the Deutsche Börse listed 95 and 77 ETFs. ${ }^{6}$ This included ETFs based on eurozone or European indices, emerging country indices, style (socially responsible, growth, value, small caps, mid caps, etc.) or sectors indices. Besides these equity-based ETFs, sponsors launched fixed-income ETFs, ETFs based on precious metals and lastly, on commodities.

\footnotetext{
${ }^{5}$ Mussavian and Hirsch (2002) present an overview of the European ETF markets at the end of the first quarter of 2002 and illustrate some possible ETF applications.

${ }^{6}$ Between January and March 2006, European marketplaces made new listings, with the launch of 40, 16, 15 and

9 ETFs, respectively, on the Deutsche Börse, the Borsa Italiana, the Swiss Stock Exchange and Euronext.
} 
Table 1: Overview of the European ETF Markets, 2005

\begin{tabular}{|c|c|c|c|c|c|}
\hline \multirow[b]{2}{*}{ Exchange } & \multicolumn{3}{|c|}{ ETFs } & \multicolumn{2}{|c|}{$\begin{array}{l}\text { Monthly average trading } \\
\text { volume }\end{array}$} \\
\hline & $\begin{array}{c}\text { Number of } \\
\text { ETFs }\end{array}$ & $\begin{array}{c}\text { Number of } \\
\text { underlying } \\
\text { indices }\end{array}$ & $\begin{array}{c}\text { Number of } \\
\text { issuers }\end{array}$ & $\begin{array}{c}\text { Number of } \\
\text { trades }\end{array}$ & $\begin{array}{c}\text { Amount } \\
\text { traded }(\mathrm{K} €)\end{array}$ \\
\hline Deutsche Börse & 77 & 68 & 9 & 18,787 & $3,842.1$ \\
\hline Euronext & 95 & 68 & 10 & 14,434 & $1,481.9$ \\
\hline London Stock Exchange & 28 & 28 & 1 & $\# \mathrm{~N} / \mathrm{A}$ & 770.2 \\
\hline Borsa Italiana & 30 & 29 & 5 & 29,964 & 727.1 \\
\hline SWX Swiss Exchange & 34 & 26 & 8 & 6,383 & 524.3 \\
\hline Virt-X & 17 & 17 & 4 & 552 & 59,8 \\
\hline OMX & 11 & 11 & 2 & 744 & 28,7 \\
\hline Wiener Börse & 11 & 10 & 2 & 119 & 19,6 \\
\hline Oslo Børs & 2 & 2 & 1 & 45 & 1,9 \\
\hline
\end{tabular}

(Data source: FESE and Deutsche Börse)

Table 1 reports ETF trading on European marketplaces for year 2005. The Deutsche Börse and Euronext account for more than $70 \%$ of the total amount traded in ETFs in Europe. A monthly average of $€ 3,842$ million was traded on the Deutsche Börse in 2005 versus $€ 1,481$ million on Euronext, although less ETFs were listed on the dominant exchange at the time. Despite continuous growth, these figures are still far from those observed in the U.S. Surprisingly the leader in the number of trades is the Borsa Italiana, with almost twice as many transactions a month as the Deutsche Börse and Euronext, but worth only $€ 0,524$ million. This highlights the difference in types of investors in the European ETF markets. In the first two markets, the trading volume essentially stems from institutional investors posting large orders, whereas the Italian market is characterized by a higher proportion of individual investors posting significantly smaller orders.

Table 1 also illustrates the competition that exists between exchanges concerning the order flow in of ETFs and between issuers for the attraction of new cash invested. The London Stock Exchange is the only European marketplace with a single ETF series, the iShares sponsored by Barclays GI. In every other exchange, there are multiple issuers managing ETFs based either on specific "home" indices or under licence from index providers. The latter represent most of the ETFs listed in Europe, with indices from STOXX, FTSE, MSCI or iBoxx, who sometimes grant multiple licences to competing issuers. For example, the 95 ETFs issued by 10 sponsors that are traded on Euronext track the performance of only 68 different underlying indices. As in the U.S., the major national (the French CAC 40, the English FTSE 100) and regional (Dow Jones EURO STOXX 50, Dow Jones STOXX 50) indices concentrate most of the assets under management as well as the 
trading volume. Typically, several ETFs use these indices as benchmark and are either listed on different European exchanges or on the same exchange. Table 2 reports basic information on the ETFs tracking the CAC 40 and the DJ Euro STOXX 50 indices competing on NextTrack as of December 31, 2005. It appears that even if those ETFs are the most traded on Euronext, the average daily number of transactions is low and highly concentrated on a single ETF for each index, namely those issued by Lyxor AM. If the same observation applies to the assets under management for the CAC 40 index with more than $€ 3$ billion, it does not apply to the DJ Euro STOXX 50. For this eurozone index, three ETFs, issued by Lyxor, Barclays, and IndExchange, have assets greater than $€ 3$ billion under management. Nonetheless, the trading volume still mostly concentrates on a single ETF. This situation is typical of the cross listing of ETFs in Europe (DJ Euro STOXX 50-based ETFs are listed on 7 different exchanges) where issuers benefit both from their nationality on their home market and more importantly, from anteriority. Investors appear to keep trading on the same ETF even when competitors are launched on the same indices. 
Table 2: CAC 40 and DJ Euro STOXX 50 Competing ETFs Listed on NextTrack

\begin{tabular}{|c|c|c|c|c|c|c|c|c|}
\hline \multirow[b]{2}{*}{ ETF } & \multirow[b]{2}{*}{ Issuer } & \multirow[b]{2}{*}{$\begin{array}{l}\text { Management } \\
\text { fess }\end{array}$} & \multirow[b]{2}{*}{$\begin{array}{l}\text { Dividend } \\
\text { frequency }\end{array}$} & \multicolumn{3}{|c|}{ Trading volume } & \multicolumn{2}{|c|}{$\begin{array}{l}\text { Assets under } \\
\text { management }\end{array}$} \\
\hline & & & & $\begin{array}{c}\# \\
\text { trades. }\end{array}$ & \# shares & $\begin{array}{c}\text { Amount } \\
(\mathrm{K} €)\end{array}$ & $\begin{array}{c}\text { \# shares } \\
\text { (thousands) }\end{array}$ & $\begin{array}{c}\text { Amount } \\
(\mathrm{K} €)\end{array}$ \\
\hline \multicolumn{9}{|c|}{ Underlying index: CAC 40} \\
\hline Lyxor ETF CAC 40 & Lyxor AM & $0.25 \%$ & annual & 242 & 466,805 & $19,856.83$ & $67,831.75$ & $3,233,539$ \\
\hline $\begin{array}{l}\text { CAC40 indexis } \\
(02 / 03 / 05)\end{array}$ & $\begin{array}{l}\text { Crédit Agricole } \\
\text { AM }\end{array}$ & $0.25 \%$ & annual & 9 & 45,375 & $1,883.48$ & $14,227.28$ & 680,170 \\
\hline $\begin{array}{l}\text { EasyETF CAC40 } \\
(17 / 03 / 05)\end{array}$ & $\begin{array}{l}\text { AXA IM, BNP } \\
\text { Paribas }\end{array}$ & $0.25 \%$ & annual & 12 & 107,997 & $4,719.19$ & $17,800.00$ & 840,516 \\
\hline \multicolumn{9}{|c|}{ Underlying index: DJ Euro STOXX 50} \\
\hline $\begin{array}{l}\text { Lyxor ETF DJ Euro } \\
\text { STOXX } 50\end{array}$ & Lyxor AM & $0.25 \%$ & annual & 85 & 544,386 & $17,425.75$ & $108,128.00$ & $3,906,665$ \\
\hline $\begin{array}{l}\text { iShares DJ Euro } \\
\text { STOXX } 50\end{array}$ & Barclays GI & $0.15 \%$ & quarterly & 20 & 149,637 & $4,830.48$ & $92,900.00$ & $3,368,483$ \\
\hline $\begin{array}{l}\text { Dow Jones Euro } \\
\text { STOXX } 50 \text { EX }\end{array}$ & $\begin{array}{l}\text { IndExchange } \\
\text { Investment AG }\end{array}$ & $0.15 \%$ & annual & 3 & 18,135 & 598.42 & $94,397.51$ & $3,460,613$ \\
\hline $\begin{array}{l}\text { EasyETF Euro } \\
\text { STOXX } 50 \text { A }\end{array}$ & $\begin{array}{l}\text { AXA IM, BNP } \\
\text { Paribas }\end{array}$ & $0.45 \%$ & $\begin{array}{l}\text { annual } \\
\text { (cap.) }\end{array}$ & 2 & 43,197 & 145.89 & $20,339.60$ & 76,477 \\
\hline $\begin{array}{l}\text { EasyETF Euro } \\
\text { STOXX } 50 \text { B } \\
\text { UBS ETF DJ EURO } \\
\text { STOXX } 50 \text { I }\end{array}$ & $\begin{array}{l}\text { AXA IM, BNP } \\
\text { Paribas } \\
\text { UBS ETF }\end{array}$ & $0.25 \%$ & $\begin{array}{l}\text { annual } \\
\text { half- } \\
\text { yearly }\end{array}$ & 2 & 19,623 & 683.51 & $1,117.80$ & 40,801 \\
\hline
\end{tabular}

Data source: NextTrack. Reported trading volumes are computed as daily averages for 2005. Complete figures for the ETF DJ EURO STOXX 50 I were not available.

\section{ETF Trading}

ETFs are hybrid instruments combining the advantages of both open-end unit trusts and closed-end funds. They combine the creation and redemption process of the former with the continuous stock market tradability of the latter. Conventional mutual funds must typically buy back their units for cash, with the disadvantage that investors can only trade once a day at the net asset value ${ }^{7}$ (NAV) computed after the close. Moreover, the trustee needs to keep a fraction of the portfolio invested in cash to meet the possible redemption outflows. Closedend funds avoid this so-called "cash drag" as investors who wish to exit the fund can trade it throughout the day on exchanges. However, as no further creations and redemptions are allowed, excess offer or demand for closed-end funds may result in significant premiums or discounts with respect to their NAV. An innovative structure has been set up for ETFs. They trade on the stock market on a continuous basis, but shares can also be created or redeemed

\footnotetext{
${ }^{7} \mathrm{NAV}$ is defined as the market value of the securities held less liabilities, all divided by the number of shares outstanding.
} 
directly from the fund. The efficiency of the ETF specific dual trading system essentially relies on the in-kind creation and redemption process that is only available to institutional investors. We will first describe the ETF trading structure and then present the different players in the ETF marketplace.

\subsection{The ETF Trading Process}

ETF trading in the major marketplaces around the world closely resembles the system that was set up in the AMEX for SPDRs. The basic idea the original designer of ETFs, Nathan Most, had was to organize ETFs as commodity warehouse receipts with the physicals delivered and stored, whereas only the receipts are traded, although holders of the receipt can take delivery. This "in-kind" creation and redemption principle has been extended from commodities to stock baskets. Market makers and institutional investors can deposit the stock basket underlying an index with the fund trustee and receive fund shares in return. The shares thus created can then be traded on an exchange as simple stocks or later redeemed for the stock basket then making up the underlying index. The interesting feature in this process is that the performance earned by an investor who creates new shares and redeems them later is equal to the index return less fees even if the composition of the index has changed in the meantime.

Figure 1 illustrates the dual structure of the ETF trading process with a primary market open to institutional investors for the creation and redemption of ETF shares in lots directly from the fund, and a secondary market where ETF shares can be traded with no limitation on order size. The conditions for the creation and redemption of shares, such as the size of creation units, can vary from one fund to another, but the equity ETF process is typically as follows.

\section{i. Creation of New Shares}

Only authorized participants (APs), typically large institutional investors who have an agreement with the fund sponsor, are allowed to create new shares, in blocks of specified minimal amounts called creation units. Creation units vary in size from one fund to another, ranging from 25000 up to 300000 shares. Most ETFs have creation units of 50000 shares, which represents an amount 500 times the dollar value of the index underlying the ETF. APs 
deposit the corresponding pre-specified stock basket plus an amount of $\operatorname{cash}^{8}$ into the fund and receive the corresponding number of shares in return. For some ETFs, creation is allowed in cash but the APs then incur higher creation fees to account for the additional cost of the transactions that the replication of the index requires. Consequently, ongoing shareholders do not bear the cost of the entry (or exit) of new shareholders.

\section{ii. Redemption of Outstanding Shares}

Shares are not individually redeemable. Investors can ask for redemption only by tendering to the trust shares in creation units. Typically, the operation is done "in-kind". Redeemers are offered the portfolio of stocks that make up the underlying index plus a cash amount in return for creation units. As is the case with creation, some funds may redeem ETF units in cash under specific terms, such as delays or costs.

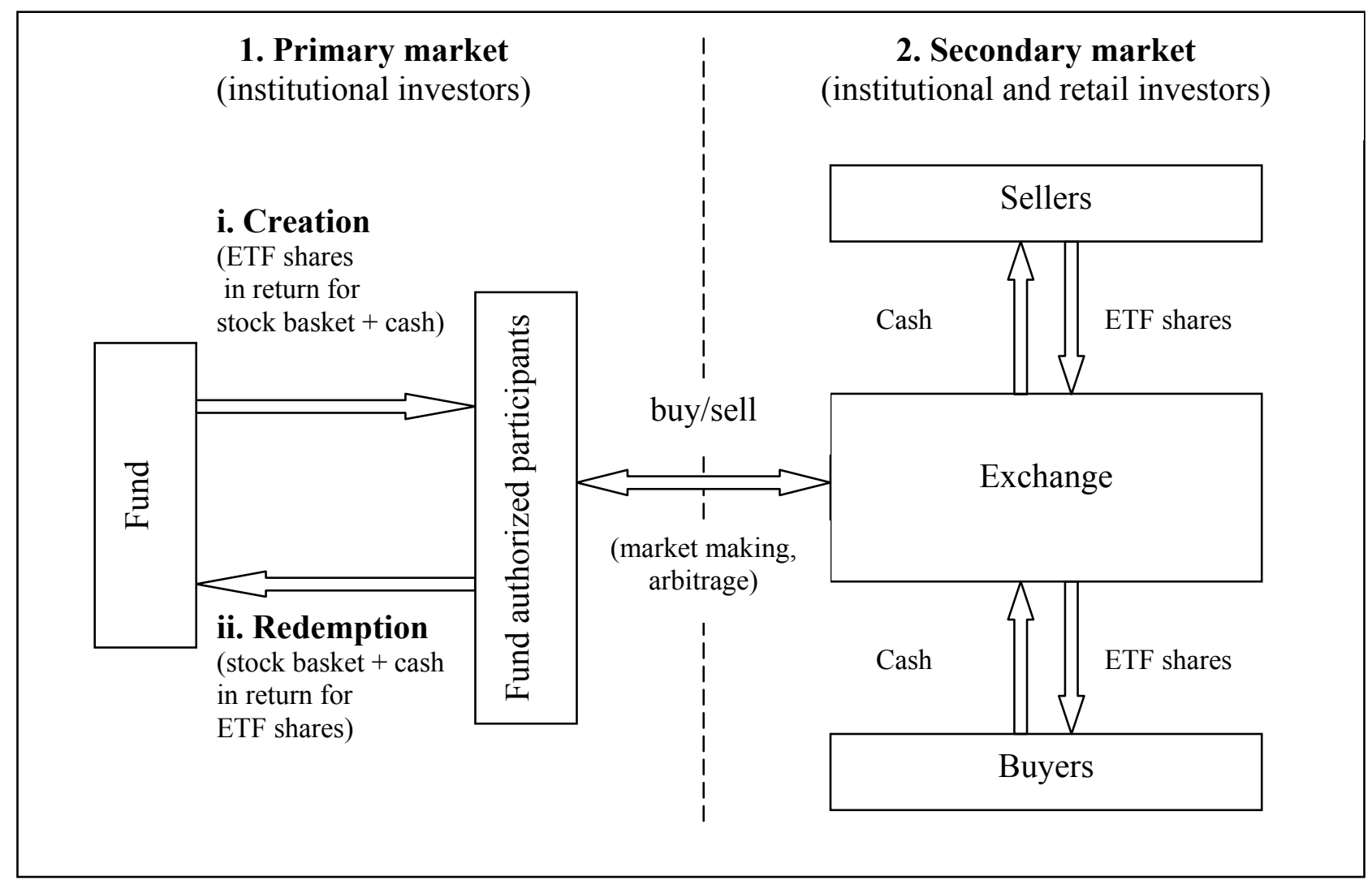

Figure 1: Primary and Secondary ETF Market Structure

The number of outstanding shares tradable on the secondary market varies over time according to creation and redemption operations carried out on the primary market. Both

\footnotetext{
${ }^{8}$ The cash component is equal to the difference between the NAV and the value of the stock basket. It accounts for the dividends cumulated by the funds, the management fees and adjustments due to rounding. This cash
} 
institutional and individual investors can buy and sell shares in the secondary market like ordinary stocks at any time during the trading day. As such, there is no fee payable for secondary market purchases or sales, but secondary market transactions are subject to regular brokerage commissions. Negotiating on the secondary market is subject to local exchange regulations. However, as index funds, ETFs typically need to receive a number of exemptions to trade like common stocks, and the launch of ETFs has generally been accompanied by the creation of dedicated market segments with their own specific rules.

In the U.S., the ETF structure could not exist under the Investment Company Act of 1940. Gastineau (2002) reviews the exemptions necessary for ETFs to exist and operate. The major exemptions are related to the permission for the "in-kind" creation and redemption process to occur only in creation units and the permission for shares to trade throughout the day at a price different from its NAV. Generally, ETFs also receive exemptions from the Securities and Exchange Act of 1934 so as to permit short-selling on a down tick, for example. In European markets, exemptions are generally embedded in the dedicated market segment regulations. On NextTrack, Euronext's dedicated market segment, besides the conventional information referring to the fund, admission to trading new ETFs is essentially subject to the nomination of at least two liquidity providers ${ }^{9}$, although Euronext is organized as a pure order book market. Moreover, specific trading halts have been required for ETFs listed on Euronext Paris since French laws stipulate that Index Funds must trade at a price that does not deviate from their NAV by more than $1.5 \%{ }^{10}$.

\subsection{The Importance of "In-Kind" Creations and Redemptions}

Since an ETF may be negotiated on two markets, it has two prices: the NAV of the shares and their market price. The first price is the value per share of the funds holdings computed at the end of each trading day. The second depends on the supply and demand for shares on the exchange. If selling or buying pressure is high, these two prices may deviate one from the other. The possibility of "in-kind" creation and redemption helps market makers absorb the liquidity shocks that might occur on the secondary market, either by redeeming outstanding shares or creating new shares directly from the fund. Moreover, the process ensures that departures are not too large. Indeed, APs could arbitrage any sizeable differences between the ETF and the underlying index component stocks. If the ETF market price fell below the

component may be negative.

${ }^{9}$ See Euronext Instruction N3-09, Avis 2000-5271. 
indicative NAV, it could be profitable for APs to buy ETFs in the secondary market, take on a short position in the underlying index stocks and then ask the fund manager to redeem the ETFs for the stock basket before closing the short position at a profit.

Another major advantage of the "in-kind" process relies on the receipt and delivery of the stock basket with its weightings specified so as to replicate the underlying index. As they need not sell any stocks on the exchange to meet redemptions, ETF fund managers can fully invest their portfolio. Moreover, creations do not yield any additional costly trading within the fund. In the U.S., "in-kind" operations are a non-taxable event, making the ETF structure seem particularly tax efficient. When confronted with massive redemptions, which often occur in bull markets, classical funds must sell their stock, resulting in taxable capital gains. When requesting redemption, APs are indifferent to the cost basis of the stocks they receive in return for the shares since their basis is the price at which they first delivered the stocks for the creation of the ETF shares. The ETF sponsor thus has the ability to deliver the stocks with the largest embedded capital gain. Historically, Dellva (2001) reports almost insignificant capital gains delivered by ETFs with respect to conventional mutual funds.

As efficient as it may be, this process is not sufficient to ensure a perfect replication of the underlying index. Changes in the composition of the index and constraints on the use of dividends and management fees induce some tracking error. Constraints depend on the legal structure chosen for the fund, but they generally remain low. Some structures allow the use of derivatives to ensure replication, whereas others restrict the holdings to the stocks that make up the index ${ }^{11}$. Loaning securities held by the fund might be permitted and is all the more profitable as the fund turnover is low and demand for its constituting stocks is high. This may help reduce management fees and expense ratios. Dividends are generally paid quarterly or half yearly. Their value includes the cumulated dividends delivered by the underlying stocks, less management fees, bringing the NAV back to the initially specified multiple of the index (usually $1 / 10^{\text {th }}$ or $1 / 100^{\text {th }}$ ).

\footnotetext{
${ }^{10}$ Decree no. 89-624, September 6, 1989.

${ }^{11}$ The major differences between the two structures used in the U.S., namely the mutual fund or the unit investment trust, will be reviewed later.
} 


\subsection{ETF Market Participants}

Besides the index providers that develop and provide licences for existing or new indices, ETF players are the stock exchanges, sponsors and trustees, ETF authorized participants, market makers and investors on the secondary market.

\section{Stock Exchanges}

A stock exchange's first task upon entering the ETF business is to define admission to trading conditions and trading rules in conjunction with market authorities and regulators. The rules depend on local regulations and often require exemptions to the existing security laws and regulations. Its second task is to provide information. Stock exchanges disseminate classical intraday and daily data on market activity such as trades and quotes, trading volume and so on. More specific information including assets under management or the number of outstanding shares is also made available. More importantly, exchanges compute and disclose indicative NAVs on a frequent basis. They are updated throughout the day so as to reflect changes in the underlying index. Investors can thus assess how far from their value ETFs trade on the marketplace. Historical data on the mean premium and discount values may also be available for each ETF. That is the case with the AMEX, for example. Usually, effective NAVs are computed and disclosed at the end of the trading day, along with the composition of the creation and redemption stock baskets.

Moreover, exchanges usually undertake marketing and educational activities to benefit investors. However, the role of stock exchanges is not limited to these regulatory and operating aspects. More specifically, the exchanges generally select which ETFs will be listed in the last resort. For example, Euronext explicitly states that it "may reject an application for admission to trading on NextTrack if the applicable conditions are not met or if Euronext believes that admission would not be in the interests of NextTrack or investors." It is unclear whether listings of competitor ETFs based on the same or close indices improve or deteriorate the market quality of their underlying stocks and other ETFs. In this respect, European exchanges have very different strategies. Contrary to Euronext and the Deutsche Börse, the Italian and English exchanges follow very restrictive listing strategies, limiting listings to very specific indices for the first and to one single sponsor for the second. Finally, exchanges can also influence the offer by providing and licensing their own indices as benchmarks for ETFs.

\section{Sponsors and Trustees}


Sponsors and trustees issue ETFs and manage the fund's holdings so as to replicate their underlying index or benchmark as closely as possible. However, in the U.S., before an ETF is admitted to trading on a stock exchange, it must pass through the SEC's exemptive process since no set of rules exists to allow firms to launch such an instrument. When a sponsor wants to cross-list his ETFs in multiple markets, the full prospectus may eventually be rewritten since, even though regulations are similar, as in Europe, different information may be needed or different presentation formats may prevail according to the country. The prospectuses provide information on the risks associated to the index replicating scheme. They also contain various information, including the list of shareholders, legal representatives and directors of the ETF's management company, the terms and conditions of the product and the way it operates. More specifically, the creation and redemption conditions are fully detailed. Replicating the performance of the underlying index is an objective, but not a mandatory one. Prospectuses include a tracking error objective, but specify that it may not be achieved. Holdings management is broadly limited to adjustments caused by changes to the index, managing dividends and creating new shares or redeeming outstanding shares. ETFs are extremely transparent since the information on the holdings and their value as well as the number of outstanding shares must be reported to the exchange and then made public.

\section{Fund Authorized Participants and Market Makers}

Although theoretically opened to all investors, the ETF primary market practically aims at the funds managers and authorized participants. Fund managers whose role has already been briefly described are responsible for issuing and redeeming trackers. Authorized participants have the fund manager's permission to request share creation and redemption, generally in multiples of the creation units. All investors requesting that creation units be created or redeemed must place an order with an AP. APs may be simple investors in the ETF fund or act as market makers on the secondary market. As with the AMEX, most ETF marketplaces have specialists or market makers. One major difference with stock markets specialists is their ability to create or redeem shares to manage their inventory risk. They play an essential role in the efficient pricing of ETFs through possible arbitrage between the ETF primary and secondary market as well as with the underlying index futures and options markets.

\section{Retail and Institutional Investors on the Secondary Market}


Most ETF trading occurs in the secondary market. That is one major advantage ETFs have over classical mutual funds. Investors need not redeem their shares to exit the fund, they can simply sell them on the market. Depending on the market and the ETF, the secondary market may be dominated either by institutional investors and APs or by retail investors. Trading ETF shares on the secondary market is organized in the same way as regular stocks, with the possible difference that there are specialists and market markers posting bid and offer prices even on order-driven markets. Short-selling, even on a down tick, and margin buying are usually allowed and ETFs may be eligible to block trades and other trading facilities.

\subsection{ETFs of Different Kinds}

\section{a. Differences in Legal Structure}

The ETF legal structure primarily depends on which exchange it is listed on. Security laws and stock exchange regulations differ from country to country. Sponsors who want to cross-list their ETFs have to accommodate multiple legal regimes. Even in the U.S., three main legal structures co-exist: open-ended index mutual funds, unit investment trusts and exchange-traded grantor trusts. ETFs are regulated by the SEC as mutual funds but, as we discussed previously, their structure is subject to a number of exemptions and there is still no set of rules that would allow new ETFs to be listed directly. Historically, the first ETFs were initially designed as Unit Investment Trusts (UIT) for simplicity and cost-saving reasons (Gastineau, 2002). Followers and most of the new ETFs preferred the more flexible structure provided by mutual funds. The main difference between the two structures is the use of dividends and the securities the fund holds. Unlike open-end index mutual funds, UITs cannot reinvest the dividends delivered by the underlying stocks ${ }^{12}$ and must cumulate them in cash. Mutual funds are also allowed to use derivatives such as futures, which allows them to equitize their dividend stream and, finally, unlike UITs, they can generate income from loaning the securities they hold. QQQs (Qubes), DIAMONDS and S\&P 500 SPDRs are structured as UITs while Select Sector SPDRs and iShares are open-end index mutual funds.

Although HOLDRs are sometimes referred to as ETFs, such exchange-traded grantor trusts cannot be considered as such according to strict definitions of the term. They are more similar to owning the underlying shares, since investors keep the right to vote shares and to

${ }^{12}$ This UIT feature results in a so-called "dividend-drag" during rising markets. As we will discuss more extensively later, it partly explains the poor performance of UITs, such as the S\&P 500 SPDR, in comparison with some of their major mutual fund competitors. See Elton et al. (2002). 
receive dividends. However, such funds do not track independent indices, given that the stocks to be included in the fund are selected based on objective criteria once the industry sector, or more generally the group of securities, has been chosen. New shares can then be created and outstanding shares can be cancelled against the delivery of the stock portfolio. The included stocks are fixed and cannot be changed even though some of the basket components are acquired by other companies.

\section{b. Differences in the Underlying Indices}

ETFs were initially meant to replicate broad-based stock indices. However, as the instrument became more familiar to investors, the universe of ETFs expanded progressively to replicate indices built around sectors, countries or styles. The process continued with the launch of fixed-income, commodity and finally currency ETFs.

Broad-based stock indices measure the performance of companies that represent a market. The number of stocks included in the index, and therefore the diversification of the associated fund, varies from one index to another, from 30 stocks in the case of the Dow Jones Industrial Average to as much as 3000 for the Russell 3000 Index (which measures the performance of the largest U.S. companies based on total market capitalization) or almost 5000 for the Dow Jones Wilshire 5000 Composite Index. Major ETFs based on broad-based stock indices include SPDRs, QQQQs, DIAMONDS or iShares Russell 2000 that replicate the S\&P 500, the Nasdaq 100, the DJIA and the Russell 2000 indices, respectively. Specific ETF series usually break down broad-based indices into "growth" and "value" management styles and small, medium or large capitalization stock sizes. With broad-based ETFs, it is possible to establish positions in global markets very quickly and equitize temporary cash positions. They may be used for long term investing, as a tool to hedge well-diversified portfolios or to implement multiple strategies. Core-satellite strategies typically use such broad-based ETFs to build the core allocation. Capitalization size trading strategies can be implemented with large, medium and small capitalization ETFs.

Country and regionally-based ETFs also generally replicate broad-based foreign equity market indices. Country ETFs replicate indices that focus on a single country, whereas regional ETFs track an index that focuses on a geographical or monetary zone such as Asia, Europe or the Eurozone. They provide easy and rapid international diversification but, since ETFs and their underlying stocks need not be traded synchronously, deviations to the NAV 
may be larger for these instruments. WEBs were the first country ETFs to be launched in 1996 and the iShares MSCI series offer worldwide country ETFs.

Broad-based indices are also generally broken down into sectors. In some instances, sector indices are designed specifically for the funds. For example, select sector SPDRs break down the overall S\&P 500 index into industry components that differ from classical S\&P sector indices (an individual security cannot account for more than $25 \%$ of the index in order to comply with the Internal Revenue Code). Other examples of sector ETF series are iShares Dow Jones, SPDR Sector Series or Merrill Lynch HOLDRs insofar as they can be considered ETFs. Sector ETFs appear to be particularly useful in implementing sector rotation strategies since they make it is easy to overweigh or underweigh sectors in a single transaction.

The first fixed-income ETFs appeared in Canada in 2000 and to date, there are only six of these products on the U.S. market, all iShares funds issued by Barclays in 2002. These were meant to replicate Goldman Sachs and Lehman Brothers bond indices, which measure the performance of obligations with different maturities and issuers, both public and corporate. Fixed-income ETFs do not mature, but maintain a portfolio that reflects the underlying bond index's target maturity. As of April 2006, fixed-income ETFs represented \$16.14 billion in assets out of a total $\$ 334.87$ billion in assets under management for the whole ETF industry. Fixed-income ETFs are used for portfolio diversification, core holding for bond portfolios or transition management, among others. European marketplaces list country-specific fixedincome ETFs.

Commodity ETFs were first launched in the U.S. with StreetTracks Gold Shares, whose objective is to reflect the performance of the gold bullion. To create new shares, APs must deposit a specified gold amount plus cash. They are redeemed the same in-kind basket in return for shares. Commodity ETFs give investors exposure to a variety of commodities such as gold, silver, oil or broad-based index commodities that include commodities from sectors as diverse as energy, metals, agriculture and livestock. Examples of such broad-based commodity ETFs include EasyETF GSCIs based on the Goldman Sachs Commodity Index (listed on the Deutsche Börse and the Swiss Stock Exchange), Lyxor ETF Commodities CRBs based on the Reuters/Jefferies CRB index (listed on Euronext) and the Deutsche Bank Commodity Index Tracking Fund and based on the Deutsche Bank Liquid Commodity Index (listed on the AMEX). Unlike classical ETFs, these funds invest in futures contracts on the underlying commodities. 
To date, the last type of ETFs to be created is currency ETFs, with the launch of Euro CurrencyShares sponsored by Rydex Investments in December 2005. It is listed on the NYSE and its objective is to reflect the price of the euro. In this last case, no derivatives are used and the Trust's assets consist only of euros on demand deposit. APs can issue and redeem shares in euro-based creation units.

\section{ETFs Pricing Efficiency}

The specificity of ETF trading is based on the creation and redemption process we presented in the previous section. Exchanges and sponsors claim that this structure necessarily brings a high pricing efficiency to the ETF market. Pricing efficiency is a major concern since trading in index funds has long been at the root of the most intriguing puzzles in finance: the closed-end fund discount. Although fund holdings are made public and the NAV is disclosed at least daily, closed-end funds generally trade at a discount to NAV. Conventional explanations for the closed-end fund puzzle $^{13}$ include biases in NAV calculation, agency costs, tax inefficiency and market segmentation. However, none of these theories can explain the full set of anomalies associated with the pricing of closed-end funds. One must forego the rational expectation framework to encompass these anomalies in a single theory. The limited rationality model developed by Lee, Shleifer and Thaler (1991) shows how the behaviour of individual investors can explain the puzzle. Misperception leads to overreaction, and the unpredictability of variations in investor sentiment makes arbitrage risky. Most of the empirical tests support this investor sentiment theory.

In contrast to closed-end funds whose capitalization is fixed, ETFs are characterized by a variable number of shares in issue. APs can ask the fund to create new shares or redeem outstanding shares with no impact on market prices and thus should be able to quickly arbitrage any deviation of the price to the NAV. No specific model that integrates the ETF arbitrage process has yet been developed. However, some empirical studies test the ability of the ETF structure to ensure efficient pricing in the U.S. ETF market. Using closing data, Ackert and Tian (2000) show that discounts on the price of SPDRs had no economic significance between 1993 and 1997, even though individual investors were the primary investors in the fund. They measure larger discounts for the MidCap SDPR based on the S\&P 400 index. This confirms the hypothesis that limits to arbitrage cause deviations given that

\footnotetext{
${ }^{13}$ For a review on the closed-end fund puzzle, see Dimson and Minio-Kozerski (1999).
} 
this ETF is likely to have higher arbitrage costs due to higher fundamental risk, transactions costs and lower dividend yield associated with its benchmark index. Discounts remain very low compared to those observed on closed-end funds and excessive volatility is only observed for MidCap SDPRs. Hence, the ETF specific structure lessens the impact of noise traders since rational traders can more easily arbitrage deviations to the NAV.

These results are confirmed by the empirical studies carried out by Elton, Gruber, Comer and Li (2002) on SPDRs, Engle and Sarkar (2002) on a sample of 21 ETFs listed on the AMEX and Curcio, Lipka and Thornton, Jr. (2004) on Cubes or Cherry (2004) on 73 iShares ETFs. Elton, Gruber, Comer and Li (2002) show that deviations to the NAV do not persist from day to day. The fact that trading volume is linked to premium and discount values supports the claim that the arbitrage mechanism is responsible for this efficiency. Engle and Sarkar (2002) examine the magnitude and persistence of discounts both daily and intradaily. On average, they find that ETFs are efficiently priced since only small deviations were seen, lasting for only a few minutes. The daily results of Curcio, Lipka and Thornton, Jr. (2004) confirm those of Ackert and Tian (2000). From an intradaily perspective, their study of transaction size proves that, even if individual investors seem to be the primary holders of SPDRs and Cubes, they account for less than one half of the trading volume. Some economically significant discounts are found, but these are very short-lived and can be attributed to institutional arbitrage activity.

The structure is the same for all ETFs but, in the case of country ETFs, the arbitrage mechanism is somewhat inhibited by non-overlapping trading hours between ETFs and their underlying index component stocks. Engle and Sarkar (2002) find that deviations to the NAV are greater and more persistent for the 16 country-ETFs sample compared to the 21 domesticETFs sample. Though imperfect, the existence of the creation/redemption process along with the high transparency of the funds holdings appears to enhance price efficiency. In effect, deviations remain smaller in magnitude (around 100 basis points on average with a maximum of $211 \mathrm{bps}$ ) than those generally observed for comparable closed-end country funds (often greater than 10\%). Jares and Lavin (2004) study this issue for Japan and Honk-Kong WEBs that trade on the AMEX. Non-tradability of the underlying stocks is an especially meaningful concern in this case since Asian markets are closed for the day before U.S. markets open. For these ETFs, an Indicated Optimized Portfolio Value serves as the Indicative NAV and is disclosed throughout the day. It is based on stale stock prices and accounts solely for changes in exchange rates. Jares and Lavin find frequent discounts and premiums for the period 
ranging from 1996 to 2001 . Moreover, there is predictability in returns giving rise to highly profitable trading rules. These results are confirmed in Madura and Richie (2004), who find reversals in prices that support the hypothesis that informed traders arbitrage overreacting investors. The measured reversals are insignificant for broad-based ETFs, but are more pronounced for international ETFs. Simon and Sternberg (2004) also find significant premiums and discounts at the end of the day and overreaction for European ETFs traded on the AMEX. Hence, if the trading system appears to enhance pricing efficiency for traded funds, some inefficiency seems to remain for ETFs replicating illiquid or foreign benchmarks.

\section{ETF Performance}

Marketing for ETFs, presented as a low-cost alternative to traditional mutual funds, has always focused on their low management fees and expense ratios. As ETFs attracted more and more cash, fierce competition between ETFs and mutual funds led to the fee war described in Dellva (2001) and Bogle (2004). Fidelity and Vanguard progressively lowered their fees and after an almost ten-year fall in expense ratios, they are now at a historical low with 10 basis points and still less for Vanguard major funds. Broad-based ETFs generally display annual expense ratios of 20 basis points or less. Recently, the expense ratio for SPDRs was lowered from $0.12 \%$ to $0.10 \%$ while Barclays' iShares S\&P 500 fees are set at $0.09 \%$. The expense ratio comparisons used as a competitive tool by issuers are obviously in favour of ETFs. However, such direct comparisons are too simplistic since they omit ETF trading costs and relative tracking performance over mutual funds.

Dellva (2001) and Kostovetsky (2003) compare both types of funds based on total costs supported by investors. ETFs generally have lower expense ratios. Investors incur transaction costs when they buy and sell ETFs while there is no supplementary cost for trading no-load mutual funds. Taxes are also of importance to taxable investors. As registered investments companies, mutual funds and ETFs must both distribute capital gains to their shareholders. If mutual funds are considered tax-friendly investments, this is even truer of ETFs. Actually, ETF managers do not need to sell shares to meet redemptions as creations/redemptions are done in-kind. More, they can also redeem shares with the higher tax basis. ETFs distribute almost no capital gains but, overall, Dellva (2001) finds that trading costs are typically higher than expense ratios and tax savings for small investors. However, as the invested amount increases, ETFs become more profitable than mutual funds, even for short-term investment of two or three years. Kostovetsky (2003) goes one step further by quantitatively modelling the 
difference in cost both in a single and multiple periods setting. He also finds that there is a threshold in the amount invested over which ETFs dominate mutual funds. However, both studies assume that there is no tracking error for both types of funds although it is well known that the replication of the benchmark index is rarely, if ever perfect.

Replication strategies cannot always be perfect. Even if most times fund holdings mimic the index composition, when it changes, fund managers must trade to adjust their holdings. The related transaction costs and possible flaws in the replication strategies induce tracking error. Elton, Gruber, Comer and Lee (2002) evidence an average $0.28 \%$ annual underperformance for SPDRs relative to the S\&P 500 index over the 1993-1998 period. Moreover, SPDRs do not favourable compare with major index mutual funds: annually, the Vanguard mutual fund that replicates the S\&P 500 index yields on average $0.18 \%$ more than the SPDRs. These results are confirmed in the study by Poterba and Shoven (2002) over the 1994-2000 period, even when taxes on capital gains delivered by both funds are taken into account. Although differences in performance are reduced, they remain economically significant. For Elton and al. (2002), 9.95 basis points are lost due to the SPDR structure. As a Unit Investment Trust, the dividends received on the fund holdings have been kept in a noninterest-bearing account until distributed to shareholders. The authors claim that investors are still investing in SPDRs rather than in relatively outperforming mutual funds because they assign value to the ability to trade their shares intradaily. The value of immediacy is 9.95 basis points. In addition to comparing SPDRs and Vanguard performances, Gastineau (2004) investigates the difference in returns between iShares Russell 2000 ETFs and Vanguard Small Cap Investor Shares over the 1994-2002 period. Irrespective of the underlying index, ETFs underperform the corresponding mutual fund. However, Gastineau attributes these differences to passiveness from ETF managers when faced with changes in index composition. Mutual fund managers typically anticipate upcoming events to reduce transaction costs embedded in the index modification process while ETF managers wait until the announcement.

To date, only a few studies deal with this issue concerning ETFs that are not based on major broad-based indices or listed in the United States. Harper, Madura and Schnusenberg (2006) extend the performance issue to country funds. Due to significantly lower expense ratios, iShares country ETFs offer higher returns than corresponding closed-end country funds. ETFs also have higher Sharpe ratios. In this case, the ETF cost efficient structure proves decisive. On the younger Australian ETF market, Gallagher and Segara (2004) do not find evidence that the streetTRACKS S\&P/ASX 200 ETF over or underperformes the mutual 
funds tracking the same index in 2002 and 2003. To our best knowledge, despite the growing success of ETFs in Europe, only one study is dedicated to the performance of European ETFs to date. For the seven most important ETFs traded on the Italian market, Zanotti and Russo (2005) show that risk-adjusted returns are higher on average than those observed for traditional mutual funds. It therefore seems that, contrary to what is observed in U.S. major broad-based indices, ETFs based on less liquid indices or listed on less mature exchanges might outperform their mutual fund counterparts.

\section{The Impact of the Introduction of ETFs on Trading and Efficiency of Related Securities}

Before the introduction of ETFs, investors could already trade stock indices intradaily through their component stocks and index derivatives. The advent of ETFs offers a new means to take quick and inexpensive positions in indices. Given their specific characteristics and organization, ETFs have attracted a significant portion of index-based trading. Either ETF investors are new to indexing or they come from the other pre-existing index markets. However, it is not very clear whether the arrival of new investors and the possible migration of existing investors from one market to another alter the mix between liquidity and informed traders for the basket and underlying stock components.

The spectacular growth of index futures markets in the 1980s had already raised the question of what impact the introduction of a basket market would have on market quality. Depending on the assumptions made about the integration of the different markets, theoretical models predict opposite effects. In the framework of perfectly integrated markets, Subramanyam (1991) and Gorton and Pennacchi (1993) model the strategic behaviour of traders who can choose to trade either in the basket stock market or the underlying stocks market. Subramanyam (1991) demonstrates that the basket security market most probably serves as the lowest-cost market for the index. Adverse selection costs are lower on the market for the basket in which the firm-specific private information is diversified. In Gorton and Pennacchi's (1993) model, liquidity traders will prefer the basket market as it enables them to build their portfolios at a lower cost. Hence, the proportion of informed traders negotiating the individual securities increases, which results in higher adverse selection costs.

In Fremault (1991) and Kumar and Seppi (1994), markets are assumed to be imperfectly integrated. The introduction of a basket instrument removes some of the obstacles that limited arbitrageurs from establishing profitable portfolios. Information asymmetry across markets 
and arbitrage costs will tend to decrease, attracting new arbitrageurs. Arbitrage activity and competition between informed traders will increase and result in higher liquidity in the individual securities market.

Hedge and McDermott (2004) transpose these predictions to the introduction of ETFs. On the one hand, the migration of liquidity trading from the stock market to the ETF market could deter the liquidity of individual securities. On the other hand, if ETFs facilitate arbitrage trading, their introduction would increase arbitrage activity and enhance both the liquidity of the underlying stocks and the efficiency of the derivatives markets. Two contrasting theories on how the introduction of ETFs modifies the established equilibriums can be tested: the "adverse selection hypothesis" and the "arbitrage hypothesis". The number of studies on this issue is still limited, but we will nonetheless divide the discussion into three parts. We will first review the studies that analyze to what extent ETF trading affects the quality of the underlying index component stocks. Then, we will look at the research that tests what impact the introduction of ETFs has on derivatives markets efficiency. Finally, we will consider works that measure how the index pricing discovery process is influenced by the high ETF trading levels.

\subsection{ETFs and the Market Quality of Their Underlying Stocks}

The advent of ETF trading is likely to have modified the mix of informed and liquidity traders on the market for individual securities. To test to what extent this is the case, empirical studies measure the importance of information asymmetries both in ETFs and individual stock markets. This research typically relies on the analysis of bid-ask spreads and trading volumes and measures the evolution of market quality after trading in ETFs becomes possible. Overall, the ETF market is found to attract very few informed trading and to be more liquid than the individual stocks market. However, there is no clear consensus on whether ETFs enhance liquidity in the underlying stocks.

Hedge and McDermott (2004) provide an in-depth analysis of the market liquidity of Diamonds and the stocks that constitute the DJIA around the launch of this ETF. Empirical pre- and post-ETF comparisons of various liquidity measures computed over two 50-day periods were used to test the impact of the ETF's introduction. Their results support the arbitrage hypothesis. The different measures of the individual stocks' liquidity improve, appearing to be mostly due to a decrease in adverse selection costs as measured with the price formation model developed by Madhavan, Richardson and Roomans (1997). Moreover, the 
trading volume and open interest of DJIA futures contracts increase over the sample period. Similar, but less significant results are obtained for the introduction of Cubes.

The study of Madura and Richie (2005) on the introduction of Cubes supports the arbitrage hypothesis. First, there is evidence of a decrease in the spreads of Nasdaq 100 index components over the three months following the introduction of Cubes compared to the preceding three-month period. Second, the decrease in the spread is all the more significant as the weight of the stock is low. This result supports the role of ETFs in the measured decrease. Passive fund managers need not invest in all securities to replicate the index. Rather, they use sampling techniques and limit their activity to the top holdings. In contrast, arbitrageurs investing in ETFs through the in-kind creation/redemption process must transact the full hundred-stock portfolio. Among these stocks, the less weighted stocks experience the largest increase in liquidity. Third, the introduction of Cubes was followed by an increase in the pricing efficiency of the individual stock and a significant decline in systematic risk. $\mathrm{Yu}$ (2005) also finds more efficient pricing and a decline in the trading costs of component stocks following the introduction of the basket security for a sample of 63 ETFs and 15 HOLDRs listed on the AMEX.

On the contrary, the results found by Van Ness, Van Ness and Warr (2005) and Ascioglu, Aydogdu, Chou and Kugele (2006) support the adverse selection hypothesis drawn from Subrahmanyam's (1991) model. Over the two-month period that brackets the introduction of Diamonds, Van Ness, Van Ness and Warr (2005) claim that liquidity traders move to the ETF market since the spreads measured for the DJIA component stock experience a smaller decline than those of the control sample. However, no significant modification is found in the adverse selection components of the individual stocks, but the authors argue that this may simply be due to the poor performance of adverse selection models in general. Ascioglu, Aydogdu, Chou and Kugele (2006) break down the spread of 64 broad-based ETFs listed on Nasdaq using Madhavan, Richardson and Roomans' (1997) methodology. In this preliminary study, tests are carried out over two months, March and April 2005. They show that information asymmetry is less severe for ETFs than it is for comparable stocks, insofar as it is possible to match the most traded ETFs with stocks.

Nonetheless, whatever the measured effect the introduction of ETFs has on individual stocks, all studies find that the ETF liquidity is higher than that of the underlying stock portfolio. For liquidity traders, ETFs appear to be a cheaper vehicle for building a diversified index portfolio compared to investing in the individual stocks directly. The study of Bennett 
and Kerins, Jr. (2003) confirms this last point for 92 ETFs listed on the AMEX over the last quarter of 2000. This remains true even though some ETFs exhibit a lower trading volume than the underlying stocks.

\subsection{ETFs and the Efficiency of the Underlying Index Derivatives}

In complete and perfect markets, arbitrage relationships tightly constrain the price of derivatives with respect to their underlying asset. On real markets, with the existence of friction and trading constraints, futures (Chung, 1991; Miller, Muthuswamy and Whaley, 1994) and options (Kamara and Miller, 1995) prices can fluctuate around their theoretical value without giving rise to arbitrage opportunities. Arbitrage relationships only impose bounds that widen with the prevalence of friction. As Ackert and Tian (2000) note, the advent of ETFs removes some of the obstacles that prohibited arbitrageurs to enter in efficiencycreating trades in index derivatives markets. Besides the possibility of shorting the index, even on a downtick, ETFs should lower both trading costs and the liquidity risk of building an index position. Moreover, in the imperfectly integrated market framework of Fremault (1991) and Kumar and Seppi (1994), the advent of ETFs should increase inter-market arbitrage activity. As a first hint in favour of these predictions, Hedge and McDermott (2004) find a significant increase in the daily average DJIA and Nasdaq-100 futures trading volume and open interest over the 101 trading days surrounding the introduction of Diamonds and Cubes, respectively.

Empirical tests that study what impact the introduction of ETFs have on the efficiency of derivatives markets first rely on the computation of arbitrage profits. The frequency and values of arbitrage opportunities measured prior to the advent of ETFs are then compared to those measured after. Though early studies use daily data, most recent works use tick-by-tick data, which eventually allows differences in the persistence of efficient value distortions to be tested. Futures markets distortions are defined with respect to cost-of-carry prices, whereas the put-call parity relationship is the main benchmark for theoretical option values even though other arbitrage relationships such as the lower boundary or constraints on spreads may set efficiency boundaries. Overall, though futures market studies highlight an improvement in inter-market efficiency, evidence for a similar pattern in the options market is mixed.

Park and Switzer (1995) test how TIPs, the very first ETF listed on the Toronto Stock Exchange, impacted the efficiency of the Toronto 35 index futures market. Using closing data, they find a reduction in arbitrage opportunities both in terms of frequency and value. 
The authors interpret this result as evidence that the TIPs lowered arbitrage costs and thus attracted more arbitrage activity. Switzer, Varson and Zghidi (2000) draw the same conclusion from the reduction in mispricings measured after SPDRs were introduced. Nonsynchronous prices do not explain the improved efficiency observed since the pattern is obtained both with daily and hourly data. As for the advent of Cubes, Kurov and Lasser (2002) work with one year of transaction data concerning the near maturity of Nasdaq-100 futures. Whatever the assumed transaction cost levels, both the size and frequency of deviations decrease once Cubes are traded. Kurov and Lasser also conduct ex ante tests that consist in building the arbitrage portfolios only after an ad-hoc period has elapsed. They document faster market reactions to observed deviations since a larger percentage of opportunities disappear within two minutes in the post-ETF period. On the French index futures market, Deville, Gresse and de Séverac (2006) investigate the impact the introduction of the Lyxor CAC 40 ETF had on the pricing efficiency of the French broad-based CAC 40 index futures over a two-year period. Even after controlling for liquidity of futures contracts and individual stocks and market volatility, ETFs appear to enhance inter-market efficiency. However, further analysis shows that this improvement cannot be directly attributed to ETF trading. Rather, the introduction of ETFs increased the liquidity of the underlying stocks which may have attracted new arbitrage activity, thus tightening the spot-futures pricing relationship.

In contrast, there is no clear evidence of improved efficiency in the options markets. Their efficiency seems to improve over time, as evidenced by Ackert and Tian (1998) on the Toronto Stock Exchange when TIPs were launched or by Ackert and Tian (2001) on the CBOE when SPDRs were launched. However, they find no clear effect on the link between stock and index options markets as measured by sole deviations to relationships that require trading in the index. No significant improvement is found in the compatibility of their closing price samples with these relationships. Opposite results are obtained with tick-by-tick data on the French market by Deville $(2003,2005)$ for the launch of CAC 40 index ETFs. The improvement of all market efficiency measures that rely on put-call parity supports the notion that ETFs improve the efficiency of the options market. Moreover, the duration of deviations drops twofold with the introduction of ETFs. Deville and Riva (2006) confirm the importance of ETFs in enhancing inter-market efficiency through a survival analysis approach. The existence of ETFs is found to be a major determinant of the process that drives prices back to values compatible with efficiency. 


\subsection{ETFs and Price Discovery}

With the creation and development of index futures, the cash market for component stocks has gradually lost its prominence in index trading. Empirically, for U.S. broad-based indices, studies that explore the dynamics of index prices show that the futures markets incorporate information more rapidly than the stock markets. However, significant, but weaker effects are measured from the latter to the first market. ETFs allow indices to be traded throughout the day at low cost and may appear to be more convenient trading vehicles than futures for smaller orders and liquidity traders. A question that naturally arises from this is whether futures contracts remain the lead instrument in the price discovery process. A byproduct of the studies on price discovery is the insightful information they provide on where uninformed and informed traders trade.

Despite the introduction of SPDRs, Chu, Hsieh and Tse (1999) show in a Vector Error Correction framework that price discovery still takes place on S\&P 500 futures. SPDRs only make a small contribution to the common factor, but more so than the spot market. Since the study is based on the ETFs' first year of trading, it is necessary to view these results with some caution. SPDRs only began to exhibit a high trading volume years later. Over the March-May 2000 period, Hasbrouck (2003) analyzes the price discovery process using the information share approach of Hasbrouck (1995) for three major U.S. indices. Investors can take positions on the S\&P 500 and Nasdaq-100 indices through individual stocks, floor-traded futures contracts, electronically-traded E-mini futures contracts, options or ETFs. The largest informational contributions come from the futures market, with the ETF market playing a minor, though significant role. Interestingly enough, there was no E-mini contract for the S\&P MidCap 400 over the sample period and the ETF information share is the most important for this last index.

Recent work by Tse, Bandyopadhyay and Shen (2006) shows that although the E-mini DJIA futures contracts dominate price discovery, Diamonds also play a very significant part in the process. Their results for the S\&P 500 highlight a contribution of about $49 \%$ for the ETF. However, this does not cast doubt on Hasbrouck's (2003) results since they are based on floor-based quotes and trades from the AMEX whereas Tse, Bandyopadhyay and Shen use quotes from the ArcaEx Electronic Crossing Network ${ }^{14}$. The anonymous and immediate

\footnotetext{
${ }^{14}$ This confirms what Tse and Erenburg (2003) find concerning the Nasdaq-100 index in that trading in ECNs contributes the most to price discovery.
} 
trading execution obtained on electronic trading platforms may indeed attract informed trading.

The results obtained by Henker and Martens (2004) contrast with the view that derivatives and ETFs are the leading instruments. They follow Hasbrouck's (1995) methodology to assess the discovery process for two liquid HOLDRs from January to July 2003. Although there are no futures contracts that could attract most of the informed trading activity, HOLDRs are dominated in the pricing discovery by component stocks. This evidence is in line with the predictions of the Subrahmanyam's (1991) model, in that the underlying stocks will lead the basket instrument.

Each stock in the S\&P 500 is also assigned to one of the nine Select Sector indices. Sector ETFs may be of interest to liquidity traders looking for specific diversification as well as to investors trading on private information at the sector-level. Even though some Sector SPDRs such as the XLK (technology) exhibit significant trading, Hasbrouck (2003) show that their information share is limited. In the period running from July 1, 2002 to September 20, 2002 the results obtained by $\mathrm{Yu}$ (2005) in a VAR framework are consistent with the view that low information production occurs at the sector level. One explanation is that the high trading costs and low liquidity that characterize these ETFs might deter liquidity trading. Consequently, Sector SPDRs are unattractive to informed traders.

\section{More Studies Devoted to ETFs}

ETFs are often presented as an alternative, either interesting or not, to other index instruments, mutual funds and derivatives. Literature on ETFs mostly takes the same perspective. ETF performance is compared to that of index mutual funds and their efficiency to that of closed-end funds. Their trading is essentially analyzed for the impact the advent of ETFs has on the efficiency of the related index markets. However, ETFs trade like stocks and a few studies started to transpose security market issues to ETFs. In particular, Boehmer and Boehmer (2003) and Tse and Erenburg (2003) study the influence the NYSE ETF listing has on the competition for order flow and market quality with regard to ETFs primarily traded on the AMEX. Furthermore, the specific ETF structure may shed new light on other classical questions. Arshanapalli, Switzer and Arbesfeld (2002) measure the impact SPDR creations and redemptions have on the SPDR market price and index component stocks. Biktimirov (2004) studies the conversion of TIPs to the i60 Fund to assess the shape of the demand curve for equities. Finally, ETFs where initially designed to offer low-cost diversification in a single 
trade, but little is known about their real use. The capacity of country ETFs to enhance international diversification is questioned by Pennathur, Delcoure and Anderson (2002) and Miffre (2004). Amenc, Malaise and Martellini (2004) illustrate the potential use of fixedincome ETFs in core-satellite portfolio management.

On July 31, 2001, for the first time in its history, the NYSE exercised Unlisted Trading Privileges ${ }^{15}$ and began trading the three majors ETFs, namely QQQQs, SPDRs and DIAs that were then primarily listed on the AMEX. On April 15, 2002, the process was continued with the addition of 27 new AMEX-listed ETFs and HOLDRs, mostly based on sector indices. As of April 2006, 270 ETFs now trade on the NYSE on an UTP basis along with 94 primary listed ETFs. The considerable ETF trading volume ${ }^{16}$ made the NYSE decide to join in the competition. Before the NYSE entered into ETFs, QQQQs, SPDRs and DIAs were already traded on the Nasdaq InterMarket, regional exchanges and the Island ECN. Tse and Erenburg (2003) focus on QQQQs to investigate to what extent NYSE trading influenced the ETF market quality as measured by liquidity, efficiency and price discovery. They find evidence that trading on the NYSE has increased competition for order since spread declined in all trading venues and the information shares of QQQQs relative to Nasdaq-100 futures increased following competition from NYSE. However, this accrued competition between different trading centres did not result in market fragmentation or increased trading costs. Boehmer and Boehmer (2003) confirm these results for the entire 30-ETF set that began trading on the NYSE. Post-NYSE liquidity is higher compared to pre-NYSE figures both in the entire market and different market centres. Further analysis supports the hypothesis that ETF market makers earned significant rents prior to the NYSE entry. However, in his discussion of Boehmer and Boehmer (2003), Peterson (2003) suggests that these results are also consistent with a segmentation hypothesis in which traders migrate to the market offering the best liquidity for their trades. Nonetheless, competition appears to enhance overall market liquidity without impeding the price discovery process. Competition between exchanges for ETF listings caused Cubes to switch their listing from AMEX to Nasdaq on December 1, 2004, with a change in ticker from QQQ to QQQQ. Broom, Van Ness and Warr (2006) show that even when trading already takes place in different market venues, the location of the primary

\footnotetext{
${ }^{15}$ An Unlisted Trading Privilege (UTP) is a right, provided by the Securities Exchange Act of 1934, that permits securities listed on any U.S. securities exchange to be traded by other such exchanges.

${ }^{16}$ Boehmer and Boehmer (2003) note that, in early 2001, Cubes, Spiders and Diamonds generated an average daily trading volume of about $\$ 5$ billion all together.
} 
listing is an important determinant of trading activity since the move resulted in a decline in trading costs, a consolidation of order flow and a less fragmented market.

ETFs are of particular interest in the study of the shape of the stock demand curve since non-informational events regarding individual stocks are likely to occur for these securities. Such events may be regular as is the case for in-kind creations and redemptions studied by Arshanapalli, Switzer and Arbesfeld (2002) or exceptional like the conversion of TIPs into a new fund that is the central point of Biktimirov (2004). The findings of Arshanapalli, Switzer and Arbesfeld (2002) concerning the impact of index composition changes and SPDR creations and redemptions from January 29, 1993 to September 29, 2001 support the downward sloping demand curve concept. Biktimirov (2004) makes use of a more specific event to examine the effect of demand on stock prices: the conversion of unredeemed TIPs 35 and TIPs 100 shares into new S\&P/TSE 60 Index Participation Fund (i60 Fund) shares that occurred on the Toronto Stock Exchange on March 6, 2000. The forty stocks in the Toronto 100 index that were not included in the S\&P/TSE 60 index (which served as a benchmark for the i60 Fund) had to be sold. Biktimirov claims that this event is completely noninformational since it has been long anticipated and is not associated with a change in the composition of the index. Selling pressure results in a decline in value both the day before conversion and the day of conversion with abnormal trading volumes. There is no change in liquidity and the price decline is permanent. All this evidence is consistent with the downward-sloping demand curve hypothesis.

The natural properties of country-ETFs for international diversification are studied by Pennathur, Delcoure and Anderson (2002). They find that the international iShares series efficiently replicates its foreign index benchmarks. However, its potential for diversification is limited due to of a high degree of exposure to U.S. equity markets. Miffre (2004) nonetheless insists on the specific advantages country-ETFs have over conventional mutual and closed-end country funds: short-selling on a downtick, low costs and tax efficiency, to name but a few. Investors are thus able to achieve superior diversification with ETFs as long as they invest significant amounts. Amenc, Malaise and Martellini (2004) measure the performance of a dynamic core-satellite approach based on fixed-income ETFs. However, ETFs only serve illustrative purposes and no empirical comparison with other investment vehicles is provided. 


\section{Conclusion and Perspectives}

ETFs are open-end index funds that trade like regular stocks on exchanges. They combine the features of conventional mutual funds and closed-end funds since new shares can be continuously created or redeemed and outstanding shares trade throughout the day on exchanges. They were initially launched in North-American markets in the early 1990s and new listings on exchanges led to more than 450 different ETFs being traded around the world with steadily increasing assets under management. What is even more spectacular is the growth in trading volume these instruments have generated. In the U.S., major ETFs are more traded than any other security. European ETF markets are younger, but they exhibit similar tendencies, with fierce competition both between issuers for new cash and between exchanges for order flow. Their success raises the issue of the organization of mutual fund trading.

Research on ETFs mostly focuses on their efficiency and performance as well as on their impact on the other index markets. Compared to closed-end funds, the specific in-kind creation and redemption process ensures a higher degree of pricing efficiency. Nonetheless, the advantages inherent to the in-kind process do not help ETF managers provide higher performance over the least-cost no-load index mutual funds. Overall, the advent of ETFs enhances the liquidity of the individual stock making up the benchmark indices and the efficiency of index derivatives markets. Finally, ETFs play a significant, though not prominent role in the price discovery process.

Despite the increasing importance of ETFs markets, literature on these topics is still scarce, although research perspectives are promising. For example, European and Asian ETFs markets are very active, but remain an almost untouched research field. The empirical, but also theoretical questions of competition between marketplaces and between ETFs tracking the same index still need to be investigated. Regulatory issues should also be included in future research as the evolution of ETF markets may lead markets and regulators to adopt new rules. This has already been the case for the so-called trade-through rule exemption implemented by SEC for ETFs studied by Hendershott and Jones (2005). Finally, new types of ETFs, such as the recent commodity ETFs, are launched on a regular basis and a study has yet to examine their specificities, trading or uses for fixed-income ETFs and ETF derivatives. 


\section{References}

Ackert L. F. and Y. S. Tian (1998). "The Introduction of Toronto Index Participation Units and Arbitrage Opportunities", Journal of Derivatives, v5(4), 44-53.

Ackert L. F. and Y. S. Tian (2000). "Arbitrage and Valuation in the Market for Standard and Poor's Depositary Receipts”, Financial Management, v29, 71-87.

Ackert L. F. and Y. S. Tian (2001). "Efficiency in Index Options Markets and Trading in Stock Baskets", Journal of Banking and Finance, v25, 1607-1634.

Amenc M., P. Malaise and L. Martellini (2004). "Revisiting Core-Satellite Investing", Journal of Portfolio Management, v31(1), 64-75.

Ascioglu A., M. Aydogdu, R. K. Chou and L. P. Kugele (2006). "An Analysis of Intraday Patterns in ETF and Common Stock Spreads", working paper.

Arshanapalli B., L. N. Switzer and J. Abersfeld (2002). "Index Participation Units and the Structure of Equity Market Demand: Evidence from New Issues and Redemption of SPDRs", working paper.

Bennet J. and F. J. Kerins, Jr (2003). "Exchange Traded Funds: Liquidity and Informed Trading Levels", working paper.

Biktimirov E. N. (2004). “The Effects of Demand on Stock Prices: Evidence from Index Fund Rebalancing”, Financial Review, v39, 455-472.

Blank, H. and P. Lam (2002). "The Development and Evolution of ETFs in North America", Investment \& Pensions Europe.

Boehmer B. and E. Boehmer (2003). “Trading your Neighbor's ETFs: Competition or Fragmentation?", Journal of Banking and Finance, v27, 1667-1703.

Bogle J. C. (2004). "Convergence: The Great Paradox?", Remarks before "The Art of Indexing" Conference.

Broom K. D., R. A. Van Ness and R. S. Warr (2006). "Cubes to Quads: The Move of the QQQ ETF from AMEX to NASDAQ", working paper.

Cherry J. (2004). "The Limits of Arbitrage: Evidence from Exchange Traded Funds", working paper, University of California, Berkeley. 
Chu Q. C., W.-L. G. Hsieh and Y. Tse (1999). "Price discovery on the S\&P 500 index markets: An analysis of spot index, index futures, and SPDRs", International Review of Financial Analysis, v8, 21-34.

Chung P. (1991). “A Transactions Data Test of Stock Index Futures Market Efficiency and Index Arbitrage Profitability", Journal of Finance, v46(5), 1791-1809.

Curcio R. J., J. M. Lipka and J. H. Thornton, Jr (2004). "Cubes and the Individual Investor", Financial Services Review, v13, 123-138.

Dellva W. L. (2001). "Exchange-Traded Funds Not for Everyone”, Journal of Financial Planning, 110-124.

Deville L. (2003). “Impact de l'introduction du tracker Master Share CAC40 sur la relation de parité call-put", Banque et Marchés, 62, 50-57.

Deville L. (2005). "Time to Efficiency in Options Markets and the Introduction of ETFs: Evidence from the French CAC40 Index”, working paper, Paris Dauphine University.

Deville L., C. Gresse and B. de Séverac (2006). "The Introduction of the CAC 40 Master Unit and the CAC 40 Index Spot-Futures Pricing Relationship", working paper, Paris Dauphine University.

Deville L. and F. Riva (2006). "The Efficiency Process in Options Markets: A Survival Analysis Approach", working paper, Paris Dauphine University.

Dimson E. and C. Minio-Kozerski (1999). "Closed-End Funds: A Survey", Financial Markets, Institutions \& Instruments, v8(2).

Elton E. J., M. J. Gruber, G. Comer and K. Li (2002). "Spiders: Where are the Bugs?", Journal of Business, v75(3), 453-472.

Engle R. and D. Sarkar (2006). "Premiums-Discounts and Exchange Traded Funds", Journal of Derivatives.

Fremault A. (1991). "Stock Index Futures and Index Arbitrage in a Rational Expectations Model", Journal of Business, v64, 523-547.

Gallagher D. R. and R. Segara (2004). "The Performance and Trading Characteristics of Exchange-Traded Funds Funds", working paper, University of New South Wales.

Gastineau G. L. (2001). “Exchange Traded Funds: An Introduction”, Journal of Portfolio Management, v27(3), 88-96. 
Gastineau G. L. (2002). The Exchange-Traded Funds Manual, John Wiley \& Sons, New York.

Gastineau G. L. (2004). “The Benchmark Index ETF Performance Problem”, Journal of Portfolio Management, v30(2), 96-103.

Gleason K. C., I. Mathur and M. A. Peterson (2004). "Analysis of Intraday Herding Behaviour Among the Sector ETFs", Journal of Empirical Finance, v11(5), 681-694.

Gorton G. and G. Pennacchi (1993). "Security Baskets and Index-Linked Securities", Journal of Business, v66, 1-27.

Harper J. T., J. Madura and O. Schnusenberg (2006). "Performance Comparison Between Exchange Traded Funds and Closed-End Country Funds", Journal of International Markets, Institutions, and Money, v16(2), 104-122.

Hasbrouck J. (1995). “One Security, Many Markets: Determining the Contributions to Price Discovery”, Journal of Finance, v50(4), 1175-1199.

Hasbrouck J. (2003). “Intraday Price Formation in U.S. Equity Index Markets”, Journal of Finance, v58(6), 2375-2399.

Hegde S. P. and J. B. McDermott (2004). “The Market Liquidity of DIAMONDS, Q's and their Underlying Stocks", Journal of Banking and Finance, v28, 1043-1067.

Hendershott T. and C. M. Jones (2005). "Trade-Through Prohibitions and Market Quality”, Journal of Financial Markets, v8, 1-23.

Henker T. and M. Martens (2004). "Price Discovery in HOLDR Security Baskets and the Underlying Stocks", working paper, University of New South Wales.

Jares T. E. and A. M. Lavin (2004). "Japan and Hong Kong ExchangeTraded Funds (ETFs): Discounts, Returns and Trading Strategies”, Journal of Financial Services Research, v25(1), 57-69.

Kostovetsky L. (2003). "Index Mutual Funds and Exchange-Traded Funds", Journal of Portfolio Management, v29(4), 80-92.

Kumar P. and D. Seppi (1994). "Information and Index Arbitrage”, Journal of Business, v67, 481-509. 
Kurov A. A. and D. J. Lasser (2002). "The Effect of the Introduction of Cubes on the Nasdaq100 Index Spot-Futures Pricing Relationship”, Journal of Futures Markets, v22(3), 197218.

Lee C. M. C., A. Shleifer and R. Thaler (1991). "Investor sentiment and the closed-end fund puzzle", Journal of Finance, v46(1), 75-109.

Madhavan A., M. Richardson and M. Roomans (1997). "Why Do Security Prices Change? A Transaction-Level Analysis of NYSE Stocks", Review of Financial Studies, v10, 1035 1064.

Madura J. and N. Richie (2004). "Overreaction of Exchange-Traded Funds During the Bubble of 1998-2002", Journal of Behavioral Finance, v5(2), 91-104.

Madura J. and N. Richie (2005). "Impact of the QQQ on Liquidity, Pricing Efficiency, and Risk of the Underlying Stocks", working paper, Susquehanna University.

Miller M. H., J. Muthuswamy and R. E. Whaley (1994). “Mean Reversion of S\&P500 Index Basis Changes: Arbitrage Induced or Statistical Illusion?”, Journal of Finance, v49(2), 479-513.

Miffre J. (2004). "Country Specific ETFs: An Efficient Approach to Global Asset Allocation”, working paper, Cass Business School.

Mussavian M. and L. Hirsch (2002). "European Exchange-Traded Funds: An overview", Journal of Alternative Investments, v5, 63-77.

Park T. H. and Switzer L. N. (1995). "Index Participation Units and the Performance of Index Futures Markets, Evidence from the Toronto 35 Index Participation Units Market”, Journal of Futures Markets, v15, 187-2000.

Pennathur A. K., N. Delcoure and D. Anderson (2002). "Diversification benefits of iShares and closed-end country funds", Journal of Financial Research, v25, 541-557.

Peterson M. (2003). "Discussion of “Trading your Neighbor's ETFs: Competition or Fragmentation?" by Boehmer and Boehmer", Journal of Banking and Finance, v27, 1705-1709.

Poterba J. M. and J. B. Shoven (2002). "Exchange-Traded Funds: A New Investment Option for Taxable Investors", American Economic Review, v92(2), 422-427. 
Simon D. P. and J. S. Sternberg (2004). "Overreaction and Trading Strategies in European iShares", working paper.

Subrahmanyam A., (1991). "A Theory of Trading in Stock Index Futures", Review of Financial Studies, v4, 17-51.

Switzer L. N., P. L. Varson and S. Zghidi (2000). "Standard and Poor's Depository Receipts and the Performance of the S\&P 500 Index Futures Market", Journal of Futures Markets, v20(8), 705-716.

Thirulamai R. S. (2003). “Active vs. Passive ETFs”, working paper.

Tse Y. and G. Erenburg (2003). "Competition for Order Flow, Market Quality, and Price Discovery in the Nasdaq 100 Index Tracking Stock", Journal of Financial Research, v26(3), 301-318.

Tse Y., P. Bandyopadhyay and Y.-P. Shen (2006). "Intraday Price Discovery in the DJIA Index Markets", working paper.

Van Ness B. F., R. A. Van Ness and R. S. Warr (2005). "The Impact of the Introduction of Index Securities on the Underlying Stocks: The Case of the Diamonds and the Dow 30", Advances in Quantitative Finance and Accounting, v2, 105-128.

Yu L. (2005). "Basket Securities, Price Formation and Informational Efficiency", working paper, Notre Dame University.

Zanotti G. and C. Russo (2005). "Exchange Traded Funds Versus Traditional Mutual Funds: A Comparative Analysis on the Italian Market”, working paper, Bocconi University. 